\title{
Recent Advances in Biomarkers and Regenerative Medicine for Diabetic Neuropathy
}

\author{
Yoshikai Fujita $^{1, *}$, Tatsufumi Murakami ${ }^{2}$ and Akihiro Nakamura ${ }^{1}$ \\ 1 Division of Pharmaceutics, Department of Pharmacology, Toxicology and Therapeutics, School of Pharmacy, \\ Showa University, 1-5-8 Hatanodai, Shinagawa-ku, Tokyo 142-8555, Japan; hironak@pharm.showa-u.ac.jp \\ 2 Department of Neurology, Kawasaki Medical School, 577 Matsushima, Kurashiki, Okayama 701-0192, Japan; \\ tatsum@med.kawasaki-m.ac.jp \\ * Correspondence: yoshiaki@pharm.showa-u.ac.jp; Tel.: +81-3-3784-8203
}

Citation: Fujita, Y.; Murakami, T.; Nakamura, A. Recent Advances in Biomarkers and Regenerative Medicine for Diabetic Neuropathy. Int. J. Mol. Sci. 2021, 22, 2301. https://doi.org/10.3390/ijms22052301

Academic Editor: Maria

Luisa Balestrieri

Received: 25 January 2021

Accepted: 16 February 2021

Published: 25 February 2021

Publisher's Note: MDPI stays neutral with regard to jurisdictional claims in published maps and institutional affiliations.

Copyright: (c) 2021 by the authors. Licensee MDPI, Basel, Switzerland. This article is an open access article distributed under the terms and conditions of the Creative Commons Attribution (CC BY) license (https:// creativecommons.org/licenses/by/ $4.0 /)$.

\begin{abstract}
Diabetic neuropathy is one of the most common complications of diabetes. This complication is peripheral neuropathy with predominant sensory impairment, and its symptoms begin with hyperesthesia and pain and gradually become hypoesthesia with the loss of nerve fibers. In some cases, lower limb amputation occurs when hypoalgesia makes it impossible to be aware of trauma or mechanical stimuli. On the other hand, up to $50 \%$ of these complications are asymptomatic and tend to delay early detection. Therefore, sensitive and reliable biomarkers for diabetic neuropathy are needed for an early diagnosis of this condition. This review focuses on systemic biomarkers that may be useful at this time. It also describes research on the relationship between target gene polymorphisms and pathological conditions. Finally, we also introduce current information on regenerative therapy, which is expected to be a therapeutic approach when the pathological condition has progressed and nerve degeneration has been completed.
\end{abstract}

Keywords: diabetic neuropathy; biomarker; regenerative medicine; supplementation therapy with exogenous; cytokines cell transplantation therapy; exosome

\section{Introduction}

Diabetic neuropathy is the earliest and most frequent complication of the three major complications associated with diabetes, but it is often not diagnosed until the disease has seriously progressed [1]. Therefore, early diagnosis is extremely important for care and treatment. This complication is peripheral neuropathy with predominant sensory impairment, and its symptoms are hyperesthesia, pain, and a gradual loss of sensation due to the loss of nerve fibers. When hypoalgesia occurs, trauma and mechanical irritation cannot be noticed; as a result, foot ulcers and gangrene may occur, leading to amputation of the lower limbs [2]. Therefore, since this disease imposes a physical and mental burden on patients and their families and decreases the quality of life, it is important to develop diagnostic methods with high sensitivity for its early detection. It has been clarified that the onset and progression of neuropathy can be suppressed by strictly controlling the blood glucose levels of diabetic patients over long periods of time [3,4]; however, it is difficult to completely prevent neuropathy. Currently, symptomatic treatment is the only option, as there is no reliable and effective treatment method.

It has been reported that up to $50 \%$ of diabetic peripheral neuropathy cases can be asymptomatic [5]. Therefore, together with clinical symptoms and neurological findings for the early detection of diabetic neuropathy, more sensitive and convenient biomarkers that detect the severity or stage progression are required. Information on the pathogenic mechanism is required for the development of biomarkers; however, there are different theories on the pathogenic mechanism of diabetic neuropathy, which makes the study of its mechanism very complicated [6]. Due to glucose uptake independent of insulin, metabolic changes occur in peripheral nerve tissue when hyperglycemic conditions persist. Due to 
damage to vascular endothelial cells of neurotrophic blood vessels and degeneration of nerve fibers (axons and Schwann cells), diabetic neuropathy finally appears. (1) Promotion of polyol metabolism, (2) promotion of the production of advanced glycation end products (AGEs), (3) an increase in free radicals, (4) a decrease in NO levels, and (5) promotion of the activity of protein kinase $\mathrm{C} \beta$ (PKC $\beta$ ) have been proposed to be involved in metabolic changes. It is reported that they function synergistically to cause this disease. Since biomarkers reflect the complexity of these etiologies and the progression of the pathological condition, several types of factors have been identified as potential biomarkers of diabetic neuropathy. These include factors closely linked to the etiology, those associated with the progression of pathological conditions such as inflammation, and molecules involved in the cellular response to vascular endothelial cell damage and neurodegeneration.

In addition to biomarkers localized in intracellular organelles or specific cells, this review focuses on systemic biomarkers, such as serum, which are less invasive and can be easily quantified. Other excellent reviews [7-9] also describe local biomarkers. In addition, since biomarkers are molecules whose levels fluctuate during disease progression, they are often the cause on their own; hence, supplementing them can slow down or restore the progress of disease. This review also outlines current information on regenerative therapy, which is expected to be a treatment method when the condition progresses and nerve degeneration is complete.

\section{Biomarkers for Diabetic Neuropathy}

In this review, biomarkers for diabetic neuropathy are divided into four groups: (a) AGE-related molecules (methyl glyoxal and glyoxalase I), (b) molecules that participate in the progression of inflammation (Toll-like receptors, TNF- $\alpha$, miR-146a, adiponectin, etc.), (c) molecules associated with nerve damage (nerve specificity enolase and semaphorin), and (d) molecules involved in nerve protection (nerve growth factor and HSP27). Group (a) is considered the causative agent of the onset of diabetic neuropathy, and the biomarkers from groups (b)-(d) are regarded as those that manifest in the late stage of disease progression. Table 1 summarizes the biomarkers for diabetic neuropathy covered in this section.

\subsection{AGE-Related Molecules}

\subsubsection{AGEs and Their Precursors}

Non-enzymatic glycation of proteins has been established as a major cause of diabetic complications, such as nephropathy and macroangiopathy. Excessive accumulation of AGEs is also observed in peripheral nerve tissue in diabetic neuropathy, which has been shown to correlate with a decrease in the number of nerve fibers [10]. Impaired axonal transport due to the modification of major axonal cytoskeletal proteins, such as tubulin, by AGEs [11] and impaired axon regeneration due to modification of the basement membrane protein laminin [12] are thought to contribute to the development of neural lesions. In addition, in knockout mice lacking AGE receptors (AGEs: RAGE), the loss of pain perception was prevented, demonstrating that RAGE expression is directly involved in the onset of neuropathy [13]. Accumulation of AGEs in nerve tissue is considered to be a major cause of the onset and progression of neuropathy in humans. However, the measurement of AGEs in tissues is difficult in terms of the collection and quantification of samples and does not seem to be suitable as a biomarker. On the other hand, reactive dicarbonyls, such as methylglyoxal and $\alpha$-oxoaldehyde (Figure 1), which are precursors of AGEs, are receiving much attention as biomarkers for predicting the onset and progression of diabetic neuropathy [14]. Bierhaus et al. [15] reported that methylglyoxal depolarizes sensory nerves, causes post-translational modification of the voltage-gated sodium channel Nav 1.8, and induces hyperalgesia. Furthermore, it was reported that the cold receptor channel transient receptor potential cation channel A1 (TRPA1) was also activated, causing temperature and mechanical hyperalgesia [16]. When methylglyoxal was administered to mice, a decrease in nerve conduction velocity and promotion of the secretion of calcitonin gene-related peptides from cutaneous nerve endings were observed, and hyperalgesia 
to heat stimulation and mechanical stimulation was induced. Similar changes were observed in streptozotocin-induced and hereditary diabetic mouse models but not in Nav 1.8 knockout mice. Likewise, microinjection of methylglyoxal into the skin of healthy human volunteers also induces chemical pain sensations and thermal hyperalgesia [17]. These findings strongly suggest that the mechanism of hyperalgesia in diabetic neuropathy is due to methylglyoxal itself. Furthermore, recent reports from animal experiments have shown that both hyperalgesia and itching and hypoalgesia are induced by direct intradermal or intrathecal injection [18]. Therefore, methylglyoxal can reproduce various symptoms of diabetic neuropathy that resemble clinical symptoms. Hansen et al. reported no association between serum methylglyoxal and the occurrence of diabetic peripheral neuropathy in a cohort of well-treated patients with short-term type 2 diabetes [19]. On the other hand, Andersen et al. [20] reported a significant association, suggesting that higher levels of methylglyoxal are identified as risk factors for the development of diabetic neuropathy Thus, there are discrepancies in the results depending on the length of the survey period, and a detailed examination is awaited.

(a)<smiles>CC(=O)C=O</smiles>

(b)<smiles>O=CC=O</smiles>

Figure 1. Advanced glycation end products (AGE)-related molecules. (a) Methylglyoxal, (b) $\alpha$-oxoaldehyde.

\subsubsection{Glyoxalase I (GLO I)}

It is well known that there is a pathway for degrading reactive dicarbonyls such as methylglyoxal in vivo by glyoxalase I (GLO I), the rate-determining enzyme [21]. Recently, it has been shown that the expression of GLO I varies in sensory neurons from two inbred strains of mice. Neuropathic symptoms, such as a decreased pain threshold and decreased intraepidermal nerve fiber density, observed in diabetic conditions are significantly suppressed in mice with high GLO I activity [22]. From these results, it can be assumed that the presence or absence of GLO I gene polymorphism affects the onset of diabetic neuropathy in humans. Multiple GLO I gene polymorphisms are known to exist, some of which have decreased enzymatic activity, suggesting that there are individual differences in GLO I activity [23]. A recent report showed a significant correlation between decreased GLO I activity in serum samples and painful diabetic neuropathy [24]. In addition, Groener et al. reported that the incidence of diabetic neuropathy was predominantly higher in type 2 diabetic patients with a mutant homozygous for C332C in the GLO I gene [25]. Thus, GLO I activity may be a useful biomarker.

\subsection{Molecules That Participate in the Progression of Inflammation \\ 2.2.1. Toll-Like Receptor (TLR)}

Toll-like receptors (TLRs) are receptors that play an important role in the innate immune response [26]; among these, TLR4 is associated with many diseases of the immune system [27]. On the other hand, in the peripheral nerves of diabetic humans and animals, infiltration of inflammatory cells, such as macrophages and lymphocytes, is observed, and the production of cytokines, such as tumor necrosis factor (TNF- $\alpha$ ) and interleukin (IL), is enhanced [28]. TLR2/4-knockout mice are less likely to develop neuropathy due to the ingestion of a high-fat diet, suggesting a relationship with the pathogenic mechanism of diabetic neuropathy [29].

Zhu et al. investigated the expression levels of TLR4 and its downstream genes in human peripheral blood mononuclear cells collected from patients with type 2 diabetes [30]. 
It was observed that the expression levels of TLR4 were increased in diabetic patients who developed neuropathy compared to those in healthy subjects and diabetic patients who did not develop neuropathy. Furthermore, the levels of TNF- $\alpha$ and IL-6 in serum were also significantly increased in diabetic patients who developed neuropathy. These results suggest that TLR4 may be a useful marker for diabetic neuropathy. However, this study was conducted only on patients with type 2 diabetes, and the number of subjects was relatively limited; therefore, further research is needed. Another group has also reported elevated levels of TNF- $\alpha$ in the serum samples of patients with diabetic neuropathy [31].

There are multiple gene polymorphisms in TLR4; the TLR4 Asp299Gly gene polymorphism participates in the decrease in IL-8 production after LPS stimulation [32]. In patients with type 2 diabetes with this polymorphism, the incidence of diabetic neuropathy was reduced [33]. However, no consensus has been reached because such a correlation was not found in reports from other groups [34].

\subsubsection{Adiponectin}

Adiponectin is an adipocytokine secreted by adipocytes and is a $30 \mathrm{kDa}$ protein. Adiponectin plays various roles in human metabolism, such as lipid regulation, glucose metabolism, and increased insulin sensitivity [35]. Several studies have investigated the relationship between serum adiponectin levels and diabetic nerve injury. Although there is an association between them, corroborating results have not always been obtained. For example, a cross-sectional study in India examined serum adiponectin in 487 patients with type 2 diabetes and found that diabetic patients with neuropathy had significantly higher levels of adiponectin than those without it [36]. Similarly, a study by Pradeepa et al. reported that a high level of adiponectin was associated with an increased incidence of neuropathy [37]. On the other hand, although serum adiponectin levels are associated with diabetic neuropathy, the KORA F4/FF4 study reported that decreased, rather than elevated, serum adiponectin levels were associated with diabetic peripheral neuropathy incidence [38]. Therefore, these conflicting studies suggest that different genetic backgrounds and target ages due to diversity in the ethnic composition of participants affect adiponectin levels in serum. However, these results also suggest that there is a relationship between serum adiponectin levels and the development of diabetic neuropathy. Therefore, adiponectin remains one of the promising biomarkers for the future, and it is expected that more standardized research will be conducted across different racial groups.

\subsubsection{MicroRNAs (miRNAs)}

miRNAs are non-coding single-stranded RNA, about 20-22 bases in length, which control gene expression by suppressing degradation or translation by complementarily binding to the 3' untranslated region of the target mRNA [39]. miRNAs are attracting attention as new biomarkers, as their expression patterns are relevant to pathophysiological processes. miR-146a is one of the miRNAs whose expression levels are reduced in the serum samples of diabetic patients [40]. Wang et al. reported that hyperglycemia downregulated miR-146a expression and elevated interleukin-1 receptor activated kinase (IRAK1) and tumor necrosis factor receptor-associated factor 6 (TRAF6) levels in dorsal root ganglia (DRG) neurons [41]. Furthermore, miR-146a has been shown to play an important role in mediating DRG neuron apoptosis under hyperglycemic conditions.

Other candidate miRNAs that could be useful biomarkers are being explored. Massaro et al. recently performed the miRNA expression profiling of peripheral blood mononuclear cells collected from 63 diabetic patients, classified them according to the type of complication [42], and identified the miRNA groups that were specifically upregulated in the diabetic neuropathy group (miR-125a-5p, miR-145-3p, miR-99b-5p, and miR-873-5p). Furthermore, serum miR-518d-3p and miR-618 were upregulated in patients with diabetic peripheral neuropathy compared to individuals without microvascular complications in a cohort study of patients with type 1 diabetes [43]. These data suggest that circulating miRNAs may serve as potential biomarkers for the diagnosis of diabetic neuropathy in the future. 


\subsection{Molecules Associated with Nerve Damage}

\subsubsection{Neuron-Specific Enolase (NSE)}

Nerve-specific enolase (NSE) is a glycolytic enzyme that exists specifically in nerve tissue and shows a high positivity rate, especially in small-cell lung cancer and neuroblastoma. Therefore, NSE is widely used as a tumor marker for detecting these diseases [44-46]. $\mathrm{Li}$ et al. investigated the relationship between blood NSE levels and diabetic neuropathy because the synthesis of these enzymes may be altered during the process of degeneration and regeneration of peripheral nerves due to the oxidative stress caused by chronic hyperglycemia [47]. The serum NSE levels were slightly higher in the type 1 and type 2 diabetic groups than in the control group. In particular, they increased in the group with neuropathy. This relationship was independent of fasting blood glucose, $\mathrm{HbA1c}$, duration of illness, diabetic type, age, gender, renal function, and serum NSE levels, which were associated with the degree of neuropathy. In addition, it has recently been reported that the value decreased not only with the onset and progression but also with the improvement in neuropathy in response to treatment [48]. This result suggests that NSE may be a marker for predicting therapeutic effects as well as for early detection of diabetic neuropathy; however, future studies, including large-scale clinical trials, are awaited.

\subsubsection{Semaphorins}

Semaphorins are a large family of proteins originally identified as axon guidance factors of the developing nervous system. They are multifunctional proteins that play important roles in various biological processes, such as immune responses, organogenesis, and angiogenesis [49-51]. Since these proteins are also involved in axon guidance during the regeneration process after damage to peripheral nerves, they may be ideal candidates as biomarkers for diabetic neuropathy. Several studies reported that these proteins were induced in peripheral nerves distal to a transection or crush injury in a ligation rat model [52,53]. In addition, the administration of recombinant Semaphorin 3A (Sema3A) protein attenuated mechanical allodynia and heat hyperalgesia in chronic constriction injury (CCI) rats [54]. In line with these observations, Wu et al. reported that higher Semaphorin 3A expression was accompanied by reduced intraepidermal nerve fiber density in the skin of diabetic patients compared with that in control subjects [55].

Table 1. Biomarkers for diabetic neuropathy mentioned in this review.

\begin{tabular}{|c|c|c|c|c|c|}
\hline $\begin{array}{l}\text { Biomarker } \\
\text { Candidate }\end{array}$ & Sample Source & $\begin{array}{l}\text { Quantitative } \\
\text { Method }\end{array}$ & Function & $\begin{array}{l}\text { Changes during } \\
\text { Neuropathy }\end{array}$ & Literature \\
\hline \multicolumn{6}{|c|}{ (a) AGEs related } \\
\hline Methylglyoxal & Human serum & HPLC & $\begin{array}{l}\text { Post-translational } \\
\text { modification of } \\
\text { voltage-gated sodium } \\
\text { channel Nav } 1.8 \text { causes } \\
\text { hyperalgesia. In addition, } \\
\text { it activates TRPA1 and } \\
\text { induces temperature and } \\
\text { mechanical hyperalgesia. }\end{array}$ & $\begin{array}{l}\text { When administered to mice, } \\
\text { hyperalgesia due to } \\
\text { thermal and mechanical } \\
\text { stimulation is induced. }\end{array}$ & [14-20] \\
\hline Glyoxalase I (GLO I) & $\begin{array}{l}\text { Mouse DRG } \\
\text { Human serum }\end{array}$ & Colorimetric method & $\begin{array}{l}\text { A rate-limiting enzyme } \\
\text { that decomposes reactive } \\
\text { dicarbonyls such as } \\
\text { methylglyoxal }\end{array}$ & $\begin{array}{l}\text { The neuropathic symptoms } \\
\text { observed in diabetic } \\
\text { conditions are significantly } \\
\text { suppressed in mice with } \\
\text { high GLO I activity. In } \\
\text { humans, decreased GLO I } \\
\text { activity is also significantly } \\
\text { correlated with the } \\
\text { frequency of painful } \\
\text { neuropathy }\end{array}$ & [21-25] \\
\hline
\end{tabular}


Table 1. Cont.

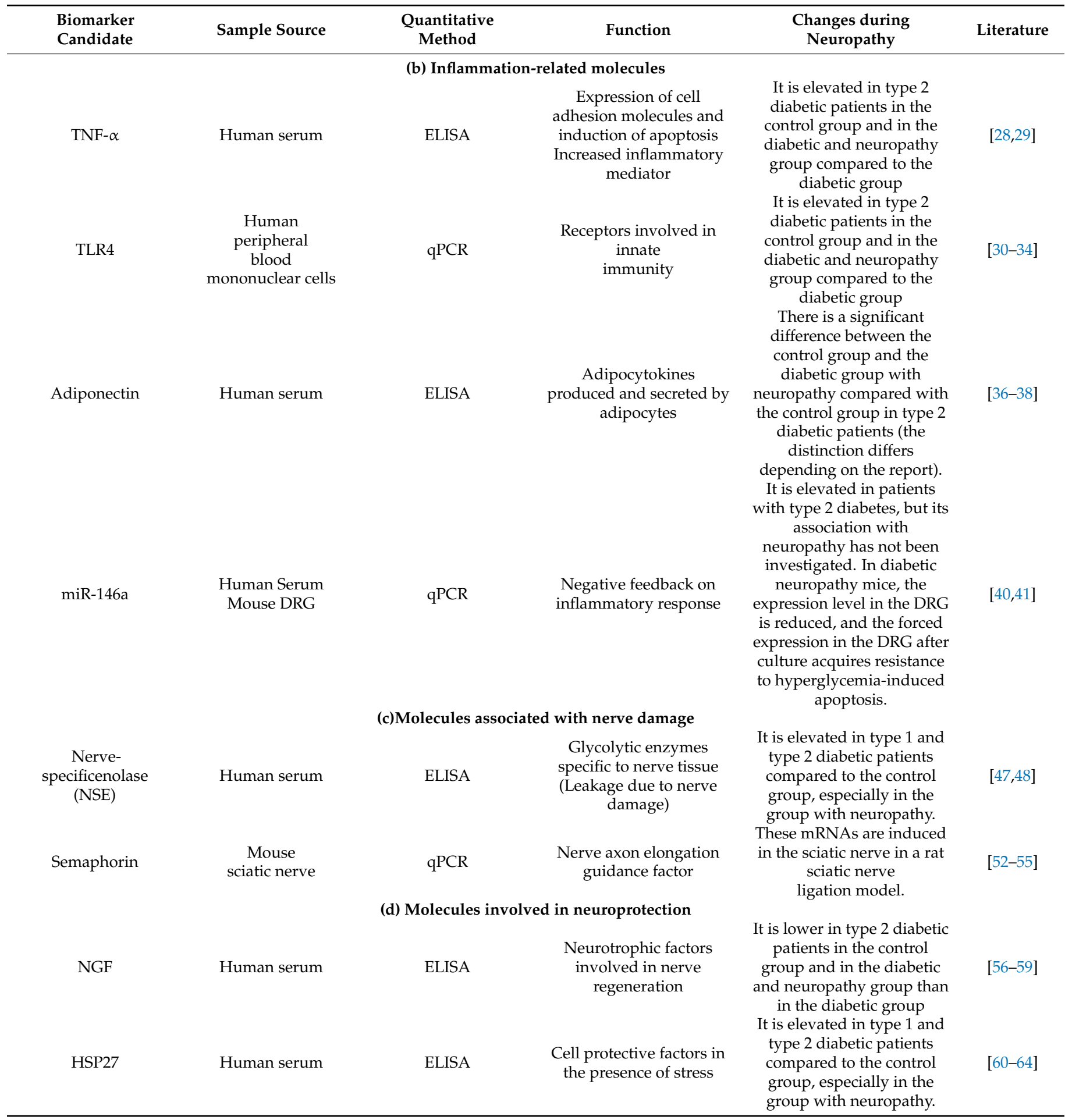

However, there is no information about changes in the expression of these genes in diabetic neuropathy animal models. Therefore, we investigated the expression levels of six types of semaphorin molecules in diabetic neuropathy model mice. As the results indicate, no statistically significant changes were observed in the expression levels of any of the molecular species (unpublished data). 


\subsection{Molecules Involved in Nerve Protection}

\subsubsection{Nerve Growth Factor (NGF)}

Neurotrophic factors are growth factors that can promote the survival and growth of neurons. In diabetic mice, decreased expression of neurotrophic factors, such as nerve growth factor (NGF), in nerve tissue or surrounding tissues was observed at the onset of neuropathy. Furthermore, the administration of exogenous nerve growth factor leads to an improvement in diabetic neuropathy [56]. Therefore, neurotrophic factors are considered to be candidates for biomarkers for diabetic neuropathy, but there are not many reports of such studies in humans. To date, there have been three reports of significantly reduced blood NGF levels in diabetic patients with neuropathy [57-59]. However, serum NGF levels were not associated with neuropathy severity in patients with diabetic peripheral neuropathy in some studies [59]. Therefore, it remains unknown whether NGF is useful enough for predicting diabetic neuropathy and understanding its pathophysiology. Further studies are required to clarify these points.

\subsubsection{Heat Shock Protein (HSP27)}

HSP27 is a small heat shock protein that plays an important role in cell protection under stress. Increased levels of HSP27 have been observed in DRG cells of the spinal cord in diabetic mice [60]. In addition, this protein plays a role in protecting Schwann cells from apoptosis [61]. Although several studies have investigated the relationship between serum HSP27 levels and patients with diabetic neuropathy [62-64], these results are conflicting. One study reported a correlation between blood HSP27 levels in patients and the occurrence of diabetic polyneuropathy. However, other reports for HSP27 were not in agreement. Further investigation, such as prospective cohort studies, is necessary to clarify this.

\section{Current Status of Regenerative Medicine}

\subsection{Supplementation Therapy with Exogenous Cytokines}

Since there is no effective therapy for diabetic neuropathic pain, symptomatic treatment is the only option. In the case of diabetic neuropathy progress in which vascular and nerve degeneration is complete, impaired nerve function cannot be restored by these treatments. Regenerative medicine is an alternative method that has the potential to restore nerve damage caused by diabetic neuropathy. It can be divided into two approaches: (1) supplementation therapy with exogenous cytokines and (2) cell transplantation therapy. In the former, several cytokines have been investigated for the treatment of diabetic neuropathy. These proteins include vascular endothelial growth factor (VEGF) [65], hepatocyte growth factor (HGF) [66], basic fibroblast growth factor (bFGF) [67], and NGF [56]. It has been shown that the gene transfer of these factors or administration of recombinant proteins elicits several limited therapeutic effects. Although most studies are limited to animal experiments, improvements in nerve blood flow and nerve function through angiogenesis in perineural tissues have been observed. For VEGF, a phase II clinical trial was conducted in humans using an expression plasmid [68]. Although no significant difference was observed in the improvement of sensory function and nerve conduction velocity 6 months after intramuscular injection, the subjective symptom score improved in that study. The intramuscular administration of an engineered zinc finger protein activator of endogenous VEGF-A showed improvement in the nerve function of the treated mice [69]. However, there are several problems with this therapy. Ectopic angioplasty cannot be fully avoided using VEGF gene therapy. VEGF expression is associated with the onset of diabetic retinopathy [70], and administration of VEGF may exacerbate retinopathy.

We have confirmed the therapeutic effect of VEGF and its homolog placental growth factor 2 (PlGF-2) gene transfer by electroporation in diabetic mice [71,72]. We also found that some isoforms (VEGF-121, PLGF-1) with angiogenic activity do not have the effect of improving nerve function. This result suggests that vascular growth factor may improve nerve function by a pathway different from the VEGF pathway, which is not relevant to 
angiogenesis. Therefore, if this putative mechanism can be elucidated, it will help in the development of therapeutic agents for new strategies.

\subsection{Cell Transplantation Therapy}

Several cell lines have been reported as a source for cell transplantation therapy. These cell lines include mononuclear cells [73], mesenchymal stem cells [74], endothelial progenitor cells [75], etc. In these studies, restoration of nerve function was attributed to several mechanisms induced by cell transplantation. It has been suggested that these cells produce angiogenesis and nerve growth factors at the transplant site and may directly affect tissue repair.

Supplementation therapy with cytokines has the problem of low expression efficiency of the introduced gene vector, and the expression of the gene is transient. On the other hand, cell transplantation therapy, a system that continuously expresses the factors necessary for tissue regeneration, is very attractive, but there is concern about its safety because the long-term continuous expression of biologically active substances may cause unexpected side effects. It is important that data on clinical efficacy and safety be accumulated for both therapies.

Exosomes are vesicles secreted by cells with a size of approximately $30-120 \mathrm{~nm}$ and have a lipid bilayer structure [76]. When first discovered, exosomes were thought to be garbage bags for discarding unnecessary cellular components. They include not only lipids and proteins but also nucleic acids, such as miRNA and mRNA. Recent studies have revealed that exosomes play an important role as signal mediators for cell-cell communication. In addition, they have regenerative properties, which encourage their application for therapeutic purposes. This approach, using exosomes, is considered to have the advantages of both cytokine replacement and cell therapy.

The application of exosomes to therapy for diabetic neuropathy has recently been reported. Lopez-Verrilli et al. observed that Schwann cell-derived exosomes (SC-exos) were internalized by DRG axons and promoted axon regeneration [77]. Wang et al. reported that SC-exos have the effect of increasing the density of intraepidermal nerve fibers in the footpad and reduce myelin damage in the sciatic nerve, which are neuropathy symptoms found in diabetic neuropathy mice [78]. On the other hand, SC-exos cultured under highglucose conditions tended to reduce epidermal nerve fibers and promote the development of diabetic neuropathy. SC-exos contained miR-21, miR-27a, and miR-146a, but the miR27a-depleted exosomes lost their effect of promoting axonal growth and Schwann cell migration in DRG neurons. Therefore, it is believed that miR-27a plays an important role in the improvement of nerve function.

Like SC-exos, exosomes derived from mesenchymal stromal cells (MSCs) have also been found to have a significant improvement effect on neuropathy symptoms after their administration in mice [79]. This effect is believed to be due to inhibition of the inflammatory response by MSC-exosomes and neurovascular remodeling.

As described above, the effectiveness of regenerative therapy for diabetic neuropathy has been proven in animal studies as summarized in Table 2. However, several problems need to be solved before medical application. In cytokine replacement therapy, a precise gene delivery system is necessary for gene therapy, which sustains the effect of cytokines at the target region. In addition, the efficacy of gene transfer is expected to have a limited duration of action when compared with cell transplantation therapy.

Cell transplantation therapy presents several problems in clinical application, such as tumorigenesis, immunological rejection, and ethical issues. Moreover, it is important to ensure the safety and quality of cells that will be therapeutically effective. Compared to the above two methods, therapy using exosomes seems to be more advantageous because it contains microRNA, cytokines, and other biologically active molecules, which are necessary substances for cell therapy itself. However, this approach also has several challenges, such as establishing cell lines to produce enough exosomes and standardizing the quality of exosomes. 
Table 2. Regenerative medicine mentioned in this review

\begin{tabular}{|c|c|c|c|}
\hline \multicolumn{4}{|c|}{ Supplementation Therapy with Exogenous Cytokines } \\
\hline & Method & Clinical Significance & Literature \\
\hline hepatocyte growth factor (HGF) & $\begin{array}{l}\text { nonviral liposome-mediated } \\
\text { gene transfer }\end{array}$ & $\begin{array}{l}\text { Improvement in nerve } \\
\text { conduction velocity }\end{array}$ & [66] \\
\hline basic fibroblast growth facto (bFGF) & $\begin{array}{l}\text { intramuscular injection of } \\
\text { recombinant bFGF protein }\end{array}$ & $\begin{array}{l}\text { Improvement in the motor nerve } \\
\text { conduction velocity of the sciatic nerve } \\
\text { and in sciatic nerve blood flow }\end{array}$ & [67] \\
\hline nerve growth factor (NGF) & recombinant protein & $\begin{array}{l}\text { Improvement of thermal allodynia in } \\
\text { streptozotocin-induced diabetic rats. }\end{array}$ & [56] \\
\hline placental growth factor 2 (PLGF-2) & $\begin{array}{l}\text { intramuscular gene transfer of } \\
\text { plasmid DNA by electroporation }\end{array}$ & $\begin{array}{l}\text { Improved hypoalgesia in diabetic mice } \\
\text { Restoration sensory nerve function }\end{array}$ & [72] \\
\hline \multicolumn{4}{|c|}{ Cell transplantation therapy } \\
\hline mononuclear cells & bone marrow & $\begin{array}{l}\text { Improvement of mechanical } \\
\text { hyperalgesia and cold allodynia in } \\
\text { streptozotocin-induced diabetic rats. } \\
\text { Improvement in sciatic motor nerve } \\
\text { conduction velocity, sensory nerve } \\
\text { conduction velocity } \\
\text { Improvement of mechanical }\end{array}$ & [73] \\
\hline mesenchymal stem cells & bone marrow & $\begin{array}{c}\text { hyperalgesia in streptozotocin-induced } \\
\text { diabetic rats. Restoration of nerve } \\
\text { conduction velocity and sciatic nerve } \\
\text { blood flow }\end{array}$ & [74] \\
\hline \multirow[t]{3}{*}{ endothelial progenitor cells } & umbilical cord blood & $\begin{array}{c}\text { Improvement in sciatic motor nerve } \\
\text { conduction velocity and sciatic nerve } \\
\text { blood flow }\end{array}$ & [75] \\
\hline & \multicolumn{2}{|l|}{ Exosome } & \\
\hline & exosome source & Clinical Significance & Literature \\
\hline Schwann cell-derived exosomes & Schwann cell & $\begin{array}{c}\text { Improvement in sciatic nerve } \\
\text { conduction velocity and increasing } \\
\text { thermal and mechanical sensitivity in } \\
\text { diabetic mouse }\end{array}$ & [78] \\
\hline $\begin{array}{l}\text { Mesenchymal stromal } \\
\text { cell-derived exosomes }\end{array}$ & bone marrow & $\begin{array}{l}\text { Improvement of thermal and } \\
\text { mechanical sensitivity in diabetic } \\
\text { mouses. Improvement in sciatic motor } \\
\text { nerve conduction velocity, } \\
\text { sensory nerve } \\
\text { conduction velocity }\end{array}$ & [79] \\
\hline
\end{tabular}

Despite these challenges, the fact remains that regenerative therapy is a promising treatment for patients with advanced disease stages. Thus, it is expected that data on clinical efficacy and safety will be accumulated for each method.

\section{Conclusions}

Diabetic neuropathy reduces the quality of life of patients. Therefore, the development of diagnostic methods for the early diagnosis of diabetic neuropathy is required. However, as described in this review, although there have been multiple candidates for biomarkers, none of them can be applied in full in clinical practice. One of the causes seems to be that the etiology of this disease is multifactorial, and in addition, the pathological condition differs depending on the course of a disease from the onset, making it difficult to approach clinically. Therefore, in order to establish a biomarker for diabetic neuropathy, it is important to select the pathological condition according to appropriate diagnostic criteria and examine it using the same method for each stage. Fortunately, the progress of comprehensive analysis technology, represented by microarray analysis and mass spectrometry 
in recent years, is remarkable, and we hope that new biomarkers will be discovered by utilizing these methods.

Author Contributions: Y.F. designed and wrote the manuscript. T.M. and A.N. improved the manuscript. All authors have read and agreed to the published version of the manuscript.

Funding: This research received no external funding.

Data Availability Statement: The data presented in this study are available on request from the corresponding author.

Acknowledgments: We gratefully acknowledge the work of past and present members of our laboratory.

Conflicts of Interest: The authors declare no conflict of interest.

\section{References}

1. Feldman, E.L.; Callaghan, B.C.; Pop-Busui, R.; Zochodne, D.W.; Wright, D.E.; Bennett, D.L.; Bril, V.; Russell, J.W.; Viswanathan, V. Diabetic neuropathy. Nat. Rev. Dis. Primers 2019, 5, 42. [CrossRef]

2. Pop-Busui, R.; Boulton, A.J.; Feldman, E.L.; Bril, V.; Freeman, R.; Malik, R.A.; Sosenko, J.M.; Ziegler, D. Diabetic Neuropathy: A Position Statement by the American Diabetes Association. Diabetes Care 2017, 40, 136-154. [CrossRef] [PubMed]

3. The Diabetes Control and Complications Trial Research Group. The effect of intenstreatment of diabetes on the development and progression of long-term complications in insulin-dependent diabetes mellitus. N. Engl. J. Med. 1993, 329, 977-986. [CrossRef]

4. Martin, C.L.; Albers, J.; Herman, W.H. Neuropathy among the diabetes control and complications trial cohort 8 years after trial completion. Diabetes Care 2006, 29, 340-344. [CrossRef] [PubMed]

5. Galer, B.S.; Gianas, A.; Jensen, M.P. Painful diabetic polyneuropathy: Epidemiology, pain description, and quality of life. Diabetes Res. Clin. Pract. 2000, 47, 123-128. [CrossRef]

6. Yagihashi, S. Glucotoxic Mechanisms and related therapeutic approaches. Int. Rev. Neurobiol. 2016, 127, 121-149.

7. Gasecka, A.; Siwik, D.; Gajewska, M.; Jaguszewski, M.J.; Mazurek, T.; Filipiak, K.J.; Postuła, M.; Eyileten, C. Early biomarkers of neurodegenerative and neurovascular disorders in diabetes. J. Clin. Med. 2020, 9, 2807. [CrossRef] [PubMed]

8. Bönhof, G.J.; Herder, C.; Strom, A.; Papanas, N.; Roden, M.; Ziegler, D. Emerging biomarkers, tools, and treatments for diabetic polyneuropathy. Endocr. Rev. 2019, 40, 153-192. [CrossRef]

9. Fan, B.; Chopp, M.; Zhang, Z.G.; Liu, X.S. Emerging roles of microRNAs as biomarkers and therapeutic targets for diabetic Neuropathy. Front. Neurol. 2020, 11, 558758. [CrossRef] [PubMed]

10. Sugimoto, K.; Nishizawa, Y.; Horiuchi, S.; Yagihashi, S. Localization in human diabetic peripheral nerve of N(epsilon)carboxymethyllysine-protein adducts, an advanced glycation endproduct. Diabetologia 1997, 40, 1380-1387. [CrossRef]

11. Sugimoto, K.; Yasujima, M.; Yagihashi, S. Role of advanced glycation end products in diabetic neuropathy. Curr. Pharm. Des. 2008, 14, 953-961. [CrossRef] [PubMed]

12. Duran-Jimenez, B.; Dobler, D.; Moffatt, S.; Rabban, N.; Streuli, C.H.; Thornalley, P.J.; Tomlinson, D.R.; Gardiner, N.J. Advanced glycation end products in extracellular matrix proteins contribute to the failure of sensory nerve regeneration in diabetes. Diabetes 2009, 58, 2893-2903. [CrossRef] [PubMed]

13. Bierhaus, A.; Haslbeck, K.M.; Humpert, P.M.; Liliensiek, B.; Dehmer, T.; Morcos, M.; Sayed, A.A.; Andrassy, M.; Schiekofer, S.; Schneider, J.G.; et al. Loss of pain perception in diabetes is dependent on a receptor of the immunoglobulin superfamily. J. Clin. Investig. 2004, 114, 1741-1751. [CrossRef] [PubMed]

14. Thornalley, P.J. Glycation in diabetic neuropathy: Characteristics, consequences, causes, and therapeutic options. Int. Rev. Neurobiol. 2002, 50, 37-57. [PubMed]

15. Bierhaus, A.; Fleming, T.; Stoyanov, S.; Leffler, A.; Babes, A.; Neacsu, C.; Sauer, S.K.; Eberhardt, M.; Schnölzer, M.; Lasitschka, F.; et al. Methylglyoxal modification of Nav1.8 facilitates nociceptive neuron firing and causes hyperalgesia in diabetic neuropathy. Nat. Med. 2012, 18, 926-933. [CrossRef] [PubMed]

16. Andersson, D.A.; Gentry, C.; Light, E.; Vastani, N.; Vallortigara, J.; Bierhaus, A.; Fleming, T.; Bevan, S. Methylglyoxal evokes pain by stimulating TRPA1. PLoS ONE 2013, 8, e77986.

17. Düll, M.M.; Riegel, K.; Tappenbeck, J.; Ries, V.; Strupf, M.; Fleming, T.; Sauer, S.K.; Namer, B. Methylglyoxal causes pain and hyperalgesia in human through C-fiber activation. Pain 2019, 160, 2497-2507. [CrossRef]

18. Cheng, R.X.; Feng, Y.; Liu, D.; Wang, Z.H.; Zhang, J.T.; Chen, L.H.; Su, C.J.; Wang, B.; Huang, Y.; Ji, R.R.; et al. The role of Na(v)1.7 and methylglyoxal-mediated activation of TRPA1 in itch and hypoalgesia in a murine model of type 1 diabetes. Theranostics 2019, 9, 4287-4307. [CrossRef]

19. Hansen, C.S.; Jensen, T.M.; Jensen, J.S.; Nawroth, P.; Fleming, T.; Witte, D.R.; Lauritzen, T.; Sandbaek, A.; Charles, M.; Fleischer, J.; et al. The role of serum methylglyoxal on diabetic peripheral and cardiovascular autonomic neuropathy: The ADDITION Denmark study. Diabet. Med. 2015, 32, 778-785. [CrossRef] [PubMed] 
20. Andersen, S.T.; Witte, D.R.; Dalsgaard, E.M.; Andersen, H.; Nawroth, P.; Fleming, T.; Jensen, T.M.; Finnerup, N.B.; Jensen, T.S.; Lauritzen, T.; et al. Risk factors for incident diabetic polyneuropathy in a cohort with screen-detected type 2 diabetes followed for 13 years: ADDITION-Denmark. Diabetes Care 2018, 41, 1068-1075. [CrossRef]

21. Thornalley, P.J. Glyoxalase I-structure, function and a critical role in the enzymatic defence against glycation. Biochem. Soc. Trans. 2003, 31, 1343-1348. [CrossRef] [PubMed]

22. Jack, M.M.; Ryals, J.M.; Wright, D.E. Protection from diabetes-induced peripheral sensory neuropathy-a role for elevated glyoxalase I? Exp. Neurol. 2012, 234, 62-69. [CrossRef]

23. Peculis, R.; Konrade, I.; Skapare, E.; Fridmanis, D.; Nikitina-Zake, L.; Lejnieks, A.; Pirags, V.; Dambrova, M.; Klovins, J. Identification of glyoxalase I polymorphisms associated with enzyme activity. Gene 2013, 515, 140-143. [CrossRef] [PubMed]

24. Skapare, E.; Konrade, I.; Liepinsh, E.; Strele, I.; Makrecka, M.; Bierhaus, A.; Lejnieks, A.; Pirags, V.; Dambrova, M. Association of reduced glyoxalase I activity and painful peripheral diabetic neuropathy in type 1 and 2 diabetes mellitus patients. J. Diabetes Complicat. 2013, 27, 262-267. [CrossRef] [PubMed]

25. Groener, J.B.; Reismann, P.; Fleming, T.; Kalscheuer, H.; Lehnhoff, D.; Hamann, A.; Roser, P.; Bierhaus, A.; Nawroth, P.P.; Rudofsky, G. C332C genotype of glyoxalase I and its association with late diabetic complications. Exp. Clin. Endocrinol. Diabetes 2013, 121, 436-439. [CrossRef] [PubMed]

26. Miyake, K. Innate immune sensing of pathogens and danger signals by cell surface Toll-like receptors. Semin. Immunol. 2007, 19, 3-10. [CrossRef]

27. Garcia, M.M.; Goicoechea, C.; Molina-Álvarez, M.; Pascual, D. Toll-like receptor 4: A promising crossroads in the diagnosis and treatment of several pathologies. Eur. J. Pharmacol. 2020, 874, 172975. [CrossRef]

28. Yamagishi, S.; Ogasawara, S.; Mizukami, H.; Yajima, N.; Wada, R.; Sugawara, A.; Yagihashi, S. Correction of protein kinase C activity and macrophage migration in peripheral nerve by pioglitazone, peroxisome proliferator activated-gamma-ligand, in insulin-deficient diabetic rats. J. Neurochem. 2008, 104, 491-499.

29. Elzinga, S.; Murdock, B.J.; Guo, K.; Hayes, J.M.; Tabbey, M.A.; Hur, J.; Feldman, E.L. Toll-like receptors and inflammation in metabolic neuropathy; a role in early versus late disease? Exp. Neurol. 2019, 320, 112967. [CrossRef]

30. Zhu, T.; Meng, Q.; Ji, J.; Lou, X.; Zhang, L. Toll-like receptor 4 and tumor necrosis factor-alpha as diagnostic biomarkers for diabetic peripheral neuropathy. Neurosci. Lett. 2015, 585, 28-32. [CrossRef] [PubMed]

31. Hussain, G.; Rizvi, S.A.; Singhal, S.; Zubair, M.; Ahmad, J. Serum levels of TNF- $\alpha$ in peripheral neuropathy patients and its correlation with nerve conduction velocity in type 2 diabetes mellitus. Diabetes Metab. Syndr. Clin. Res. Rev. 2013, 7, $238-242$. [CrossRef]

32. Long, H.; O'Connor, B.P.; Zemans, R.L.; Zhou, X.; Yang, I.V.; Schwartz, D.A. The Toll-like receptor 4 polymorphism Asp299Gly but not Thr399Ile influences TLR4 signaling and function. PLoS ONE 2014, 9, e93550. [CrossRef] [PubMed]

33. Rudofsky, G., Jr.; Reismann, P.; Witte, S.; Humpert, P.M.; Isermann, B.; Chavakis, T.; Tafel, J.; Nosikov, V.V.; Hamann, A.; Nawroth, P.; et al. Asp299Gly and Thr399Ilegenotypes of the TLR4 gene are associated with a reduced prevalence of diabetic neuropathy in patients with type 2 diabetes. Diabetes Care 2004, 27, 179-183. [CrossRef]

34. Buraczynska, M.; Zukowski, P.; Ksiazek, K.; Wacinski, P.; Dragan, M. The effect of Toll-like receptor 4 gene polymorphism on vascular complications in type 2 diabetes patients. Diabetes Res. Clin. Pract. 2016, 116, 7-13. [CrossRef] [PubMed]

35. Maeda, N.; Funahashi, T.; Matsuzawa, Y.; Shimomura, I. Adiponectin, a unique adipocyte-derived factor beyond hormones Atherosclerosis 2020, 292, 1-9. [CrossRef] [PubMed]

36. Rodriguez, A.J.; Nunes, V.S.; Mastronardi, C.A.; Neeman, T.; Paz-Filho, G.J. Association between circulating adipocytokine concentrations and microvascular complications in patients with type 2 diabetes mellitus: A systematic review and meta-analysis of controlled cross-sectional studies. J. Diabetes Complicat. 2016, 30, 357-367. [CrossRef] [PubMed]

37. Pradeepa, R.; Surendar, J.; Indulekha, K.; Chella, S.; Anjana, R.M.; Mohan, V. Association of serum adiponectin with diabetic microvascular complications among south Indian type 2 diabetic subjects-(CURES-133). Clin. Biochem. 2015, 48, 33-38. [CrossRef] [PubMed]

38. Herder, C.; Kannenberg, J.M.; Huth, C.; Carstensen-Kirberg, M.; Rathmann, W.; Koenig, W.; Heier, M.; Püttgen, S.; Thorand, B.; Peters, A.; et al. Proinflammatory cytokines predict the incidence and progression of distal sensorimotor polyneuropathy: KORA F4/FF4 Study. Diabetes Care 2017, 40, 569-576. [CrossRef]

39. Kato, M.; Castro, N.E.; Natarajan, R. MicroRNAs: Potential mediators and biomarkers of diabetic complications. Free Radic. Biol. Med. 2013, 64, 85-94. [CrossRef] [PubMed]

40. Baldeón, R.L.; Weigelt, K.; de Wit, H.; Ozcan, B.; van Oudenaren, A.; Sempértegui, F.; Sijbrands, E.; Grosse, L.; Freire, W.; Drexhage, H.A.; et al. Decreased serum level of miR-146a as sign of chronic inflammation in Type 2 diabetic patients. PLoS ONE 2014, 9, e115209. [CrossRef]

41. Wang, L.; Chopp, M.; Szalad, A.; Zhang, Y.; Wang, X.; Zhang, R.L.; Liu, X.S.; Jia, L.; Zhang, Z.G. The role of miR-146a in dorsal root ganglia neurons of experimental diabetic peripheral neuropathy. Neuroscience 2014, 259, 1551-1563. [CrossRef]

42. Massaro, J.D.; Polli, C.D.; Costa, E.; Silva, M.; Alves, C.C.; Passos, G.A.; Sakamoto-Hojo, E.T.; Rodrigues de Holanda Miranda, W.; Bispo Cezar, N.J.; Rassi, D.M.; et al. Post-transcriptional markers with clinical complications in Type 1 and Type 2 diabetes mellitus. Mol. Cell. Endocrinol. 2019, 490,1-14. [CrossRef] [PubMed] 
43. Santos-Bezerra, D.P.; Santos, A.S.; Guimarães, G.C.; Admoni, S.N.; Perez, R.V.; Machado, C.G.; Pelaes, T.S.; Passarelli, M.; Machado, U.F.; Queiroz, M.S.; et al. Micro-RNAs 518d-3p and 618 are upregulated in individuals with Type 1 diabetes with multiple microvascular complications. Front. Endocrinol. 2019, 10, 385. [CrossRef]

44. Kulpav, J.; Wójcik, E.; Reinfuss, M.; Kołodziejski, L. Carcinoembryonic antigen, squamous cell carcinoma antigen, CYFRA 21-1, and neuron-specific enolase in squamous cell lung cancer patients. Clin. Chem. 2002, 48, 1931-1937. [CrossRef]

45. Carney, D.N.; Marangos, P.J.; Ihde, D.C.; Bunn, P.A., Jr.; Cohen, M.H.; Minna, J.D.; Gazdar, A.F. Serum neuron-specific enolase: A marker for disease extent and response to therapy of small-cell lung cancer. Lancet 1982, 1, 583-585. [CrossRef]

46. Ishiguro, Y.; Kato, K.; Shimizu, A.; Ito, T.; Nagaya, M. High levels of immunoreactive nervous system-specific enolase in sera of patients with neuroblastoma. Clin. Chim. Acta 1982, 121, 173-180. [CrossRef]

47. Li, J.; Zhang, H.; Xie, M.; Yan, L.; Chen, J.; Wang, H. NSE, a potential biomarker, is closely connected to diabetic peripheral neuropathy. Diabetes Care 2013, 36, 3405-3410. [CrossRef]

48. Anju, M.; Maiya, A.G.; Hande, M.; Binu, V.S. Effect of photobiomodulation on serum neuron specific enolase (NSE) among patients with diabetic peripheral neuropathy-A pilot study. Diabetes Metab. Syndr. Clin. Res. Rev. 2020, 14, $1061-1063$.

49. Tamagnone, L.; Comoglio, P.M. To move or not to move? Semaphorin signalling in cell migration. EMBO Rep. 2004, 5, 356-361. [CrossRef] [PubMed]

50. Zhou, Y.; Gunput, R.A.; Pasterkamp, R.J. Semaphorin signaling: Progress made and promises ahead. Trends Biochem. Sci. 2008, 33, 161-710. [CrossRef] [PubMed]

51. Nishide, M.; Kumanogoh, A. The role of semaphorins in immune responses and autoimmune rheumatic diseases. Nat. Rev. Rheumatol. 2018, 14, 19-31. [CrossRef]

52. Scarlato, M.; Ara, J.; Bannerman, P.; Scherer, S.; Pleasure, D. Induction of neuropilins-1 and -2 and their ligands; Sema3A, Sema3F, and VEGF, during Wallerian degeneration in the peripheral nervous system. Exp. Neurol. 2003, 183, 489-498. [CrossRef]

53. Ara, J.; Bannerman, P.; Hahn, A.; Ramirez, S.; Pleasure, D. Modulation of sciatic nerve expression of class 3 semaphorins by nerve injury. Neurochem. Res. 2004, 29, 1153-1159. [CrossRef]

54. Hayashi, M.; Kamiya, Y.; Itoh, H.; Higashi, T.; Miyazaki, T.; Funakoshi, K.; Yamashita, N.; Goshima, Y.; Andoh, T.; Yamada, Y.; et al. Intrathecally administered Sema3A protein attenuates neuropathic pain behavior in rats with chronic constriction injury of the sciatic nerve. Neurosci. Res. 2011, 69, 17-24. [CrossRef] [PubMed]

55. Wu, L.Y.; Li, M.; Qu, M.L.; Li, X.; Pi, L.H.; Chen, Z.; Zhou, S.L.; Yi, X.Q.; Shi, X.J.; Wu, J.; et al. High glucose up-regulates Semaphorin 3A expression via the mTOR signaling pathway in keratinocytes: A potential mechanism and therapeutic target for diabetic small fiber neuropathy. Mol. Cell. Endocrinol. 2018, 472, 107-116. [CrossRef]

56. Apfel, S.C.; Arezzo, J.C.; Brownlee, M.; Federoff, H.; Kessler, J.A. Nerve growth factor administration protects against experimental diabetic sensory neuropathy. Brain Res. 1994, 634, 7-12. [CrossRef]

57. Sun, Q.; Tang, D.D.; Yin, E.G.; Wei, L.L.; Chen, P.; Deng, S.P.; Tu, L.L. Diagnostic significance of serum levels of nerve growth factor and brain derived neurotrophic factor in diabetic peripheral neuropathy. Med. Sci. Monit. 2018, 24, 5943-5950. [CrossRef]

58. Faradji, V.; Sotelo, J. Low serum levels of nerve growth factor in diabetic neuropathy. Acta Neurol. Scand. 1990, 81, 402-406. [CrossRef] [PubMed]

59. Kim, H.C.; Cho, Y.J.; Ahn, C.W.; Park, K.S.; Ki, J.C.; Nam, J.S.; Im, Y.S.; Lee, J.E.; Lee, S.C.; Lee, H.K. Nerve growth factor and expression of its receptors in patients with diabetic neuropathy. Diabet. Med. 2009, 26, 1228-1234. [CrossRef]

60. Kamiya, H.; Zhangm, W.; Sima, A.A. Apoptotic stress is counterbalanced by survival elements preventing programmed cell death of dorsal root ganglions in subacute type 1 diabetic BB/Wor rats. Diabetes 2005, 54, 3288-3295. [CrossRef]

61. Benn, S.C.; Perrelet, D.; Kato, A.C. Hsp27 upregulation and phosphorylation is required for injured sensory and motor neuron survival. Neuron 2002, 36, 45-56. [CrossRef]

62. Pourhamidi, K.; Skärstrand, H.; Dahlin, L.B.; Rolandsson, O. HSP27 concentrations are lower in patients with type 1 diabetes and correlate with large nerve fiber dysfunction. Diabetes Care 2014, 37, e49-e50. [CrossRef]

63. Pourhamidi, K.; Dahlin, L.B.; Boman, K.; Rolandsson, O. Heat shock protein 27 is associated with better nerve function and fewer signs of neuropathy. Diabetologia 2011, 54, 3143-3149. [CrossRef] [PubMed]

64. Gruden, G.; Bruno, G.; Chaturvedi, N.; Burt, D.; Schalkwijk, C.; Pinach, S.; Stehouwer, C.D.; Witte, D.R.; Fuller, J.H.; Perin, P.C.; et al. Serum heat shock protein 27 and diabetes complications in the EURODIAB prospective complications study: A novel circulating marker for diabetic neuropathy. Diabetes 2008, 57, 1966-1970. [CrossRef] [PubMed]

65. Schratzberger, P.; Walter, D.H.; Rittig, K.; Bahlmann, F.H.; Pola, R.; Curry, C.; Silver, M.; Krainin, J.G.; Weinberg, D.H.; Ropper, A.H. Reversal of experimental diabetic neuropathy by VEGF gene transfer. J. Clin. Investig. 2001, 107, 1083-1092. [CrossRef] [PubMed]

66. Kato, N.; Nemoto, K.; Nakanishi, K.; Morishita, R.; Kaneda, Y.; Uenoyama, M.; Ikeda, T.; Fujikawa, K. Nonviral gene transfer of human hepatocyte growth factor improves streptozotocin-induced diabetic neuropathy in rats. Diabetes 2005, 54, 846-854. [CrossRef]

67. Nakae, M.; Kamiya, H.; Naruse, K.; Horio, N.; Ito, Y.; Mizubayashi, R.; Hamada, Y.; Nakashima, E.; Akiyama, N.; Kobayashi, Y.; et al. Effects of basic fibroblast growth factor on experimental diabetic neuropathy in rats. Diabetes 2006, 55, 1470-1477. [CrossRef]

68. Ropper, A.H.; Gorson, K.C.; Gooch, C.L.; Weinberg, D.H.; Pieczek, A.; Ware, J.H.; Kershen, J.; Rogers, A.; Simovic, D.; Schratzberger, P.; et al. Vascular endothelial growth factor gene transfer for diabetic polyneuropathy: A randomized, doubleblinded trial. Ann. Neurol. 2009, 65, 386-393. [CrossRef] 
69. Pawson, E.J.; Duran-Jimenez, B.; Surosky, R.; Brooke, H.E.; Spratt, S.K.; Tomlinson, D.R.; Gardiner, N.J. Engineered zinc finger protein-mediated VEGF-a activation restores deficient VEGF-a in sensory neurons in experimental diabetes. Diabetes 2010, 59, 509-518. [CrossRef]

70. Caldwell, R.B.; Bartoli, M.; Behzadian, M.A.; El-Remessy, A.E.; Al-Shabrawey, M.; Platt, D.H.; Liou, G.I.; Caldwell, R.W. Vascular endothelial growth factor and diabetic retinopathy: Role of oxidative stress. Curr. Drug Targets 2005, 6, 511-524. [CrossRef]

71. Murakami, T.; Arai, M.; Sunada, Y.; Nakamura, A. VEGF 164 gene transfer by electroporation improves diabetic sensory neuropathy in mice. J. Gene Med. 2006, 8, 773-781. [CrossRef]

72. Murakami, T.; Imada, Y.; Kawamura, M.; Takahashi, T.; Fujita, Y.; Sato, E.; Yoshitomi, H.; Sunada, Y.; Nakamura, A. Placental growth factor-2 gene transfer by electroporation restores diabetic sensory neuropathy in mice. Exp. Neurol. 2011, 227, 95-202. [CrossRef] [PubMed]

73. Naruse, K.; Sato, J.; Funakubo, M.; Hata, M.; Nakamura, N.; Kobayashi, Y.; Kamiya, H.; Shibata, T.; Kondo, M.; Himeno, T.; et al. Transplantation of bone marrow-derived mononuclear cells improves mechanical hyperalgesia; cold allodynia and nerve function in diabetic neuropathy. PLoS ONE 2011, 6, e27458. [CrossRef] [PubMed]

74. Shibata, T.; Naruse, K.; Kamiya, H.; Kozakae, M.; Kondo, M.; Yasuda, Y.; Nakamura, N.; Ota, K.; Tosaki, T.; Matsuki, T.; et al. Transplantation of bone marrow-derived mesenchymal stem cells improves diabetic polyneuropathy in rats. Diabetes 2008, 57, 3099-3107. [CrossRef] [PubMed]

75. Naruse, K.; Hamada, Y.; Nakashima, E.; Kato, K.; Mizubayashi, R.; Kamiya, H.; Yuzawa, Y.; Matsuo, S.; Murohara, T.; Matsubara, T.; et al. Therapeutic neovascularization using cord blood-derived endothelial progenitor cells for diabetic neuropathy. Diabetes 2005, 54, 1823-1828. [CrossRef] [PubMed]

76. Urbanelli, L.; Buratta, S.; Sagini, K.; Ferrara, G.; Lanni, M.; Emiliani, C. Exosome-based strategies for diagnosis and therapy. Recent Pat. CNS Drug Discov. Discontin. 2015, 10, 10-27. [CrossRef]

77. Lopez-Verrilli, M.A.; Picou, F.; Court, F.A. Schwann cell-derived exosomes enhance axonal regeneration in the peripheral nervous system. Glia 2013, 61, 1795-1806. [CrossRef] [PubMed]

78. Wang, L.; Chopp, M.; Szalad, A.; Lu, X.; Zhang, Y.; Wang, X.; Cepparulo, P.; Lu, M.; Li, C.; Zhang, Z.G. Exosomes derived from Schwann cells ameliorate peripheral neuropathy in type 2 diabetic mice. Diabetes 2020, 69, 749-759. [CrossRef] [PubMed]

79. Fan, B.; Li, C.; Szalad, A.; Wang, L.; Pan, W.; Zhang, R.; Chopp, M.; Zhang, Z.G.; Liu, X.S. Mesenchymal stromal cell-derived exosomes ameliorate peripheral neuropathy in a mouse model of diabetes. Diabetologia 2020, 63, 431-443. [CrossRef] 